\title{
Synthesis of meso-substituted dihydro-1,3-oxazinoporphyrins
}

\author{
Satyasheel Sharma and Mahendra Nath ${ }^{*}$
}

\section{Full Research Paper}

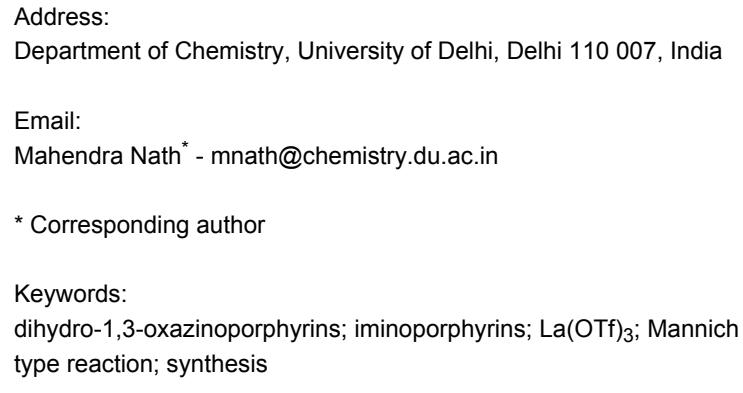

Beilstein J. Org. Chem. 2013, 9, 496-502.

doi:10.3762/bjoc.9.53

Received: 03 November 2012

Accepted: 05 February 2013

Published: 07 March 2013

Associate Editor: T. J. J. Müller

(c) 2013 Sharma and Nath; licensee Beilstein-Institut. License and terms: see end of document.

\begin{abstract}
Novel dihydro-1,3-oxazinoporphyrins and naphtho[e]bis(dihydro-1,3-oxazinoporphyrin) derivatives, in which the porphyrin macrocycle is covalently linked to the dihydro-1,3-oxazine ring system were successfully synthesized from 5-(4-aminophenyl)-10,15,20triphenylporphyrin in good yields. The structures of the target products were established on the basis of spectral data and elemental analyses.
\end{abstract}

\section{Introduction}

Porphyrin macrocycles are of crucial interest for their potential applications in diverse fields such as biomimetic models for photosynthesis [1,2], electronic materials [3], catalysis [4] and medicine $[5,6]$. In the past few decades, the synthesis of porphyrin derivatives has emerged as one of the major areas of research due to the success of these molecules for the eradication of malignant cells by photodynamic therapy (PDT) after their selective accumulation [7-10] in neoplastic tissues. In addition, the low dark-toxicity profile, easy removal from the tissue, and efficiency in generating reactive oxygen species by the absorption of photons in the visible or near IR region make them ideal candidates for developing effective photodynamic agents. These findings have encouraged researchers to design and synthesize potential targeting anticancer drugs derived from porphyrins $[11,12]$. Previously, a large number of these molecules have been synthesized by the coupling of diverse pharma- ceutically important moieties, such as carbohydrates [13-15], amino acid residues [16-19], steroids [20,21], glycosides [2224], nitroxyl derivatives [25], pyrrolidinone [26], pyrrolidine [27] and piperazine [28], to the porphyrin periphery. In addition, many porphyrin dimers and trimers have displayed significant biological efficacy [29] and some of these are used as photosensitizers in PDT applications for the treatment of various types of cancers [30].

Thorough literature search revealed that heterocycles containing a dihydro-1,3-oxazine ring system exhibit a wide spectrum of pharmacological activities, for example, acting as antimicrobial [31-33], anti-HIV [34], antimalarial [35] or antitumor agents $[36,37]$. By considering the anticancer significance of these two classes of molecules, it was contemplated to construct new dihydro-1,3-oxazinoporphyrins combining the porphyrin and 
dihydro-1,3-oxazine moieties in a single molecular framework. Such hybrid compounds may prove useful for pharmacological studies or in the development of new phototherapeutic agents. Therefore, in continuation of our efforts towards the synthesis of diverse porphyrin analogues [38-41] through peripheral functionalization of easily accessible meso-tetraarylporphyrins, we now report herein the first synthesis and spectroscopic characterization of a novel series of dihydro-1,3-oxazinoporphyrins.

\section{Results and Discussion}

The targeted dihydro-1,3-benzoxazinoporphyrins 6-9 were prepared in a three step procedure, starting from 5-(4aminophenyl)-10,15,20-triphenylporphyrin (1), which was obtained by the reduction of 5-(4-nitrophenyl)-10,15,20-triphenylporphyrin using $\mathrm{SnCl}_{2}$ under acidic conditions [41,42]. Firstly, meso-(4-aminophenyl)porphyrin 1 was reacted with salicylaldehyde or 5-chlorosalicylaldehyde in the presence of $\mathrm{La}(\mathrm{OTf})_{3}$ as a Lewis acid catalyst in toluene under reflux to afford the corresponding iminoporphyrins $\mathbf{2}$ and $\mathbf{3}$, which on reduction by $\mathrm{NaBH}_{4}$ in a chloroform/methanol mixture at $25{ }^{\circ} \mathrm{C}$ produced meso-substituted aminoporphyrins 4 and 5 , respectively. In the final step, these aminoporphyrins underwent a condensation cyclization reaction with aldehydes in THF under reflux to form new dihydro-1,3-benzoxazinoporphyrins 6-9 in good yields. Further, these free-base porphyrins were successfully converted to their zinc(II) analogues 10-13 by using $\mathrm{Zn}(\mathrm{OAc})_{2} \cdot 2 \mathrm{H}_{2} \mathrm{O}$ as outlined in Scheme 1.

In contrast, the synthesis of new dihydro-1,3-naphthoxazinoporphyrins 14 and 16 was achieved in 75-85\% yields in a one-pot three-component Mannich type condensation-cyclization reaction of 5-(4-aminophenyl)-10,15,20-triphenylporphyrin (1)

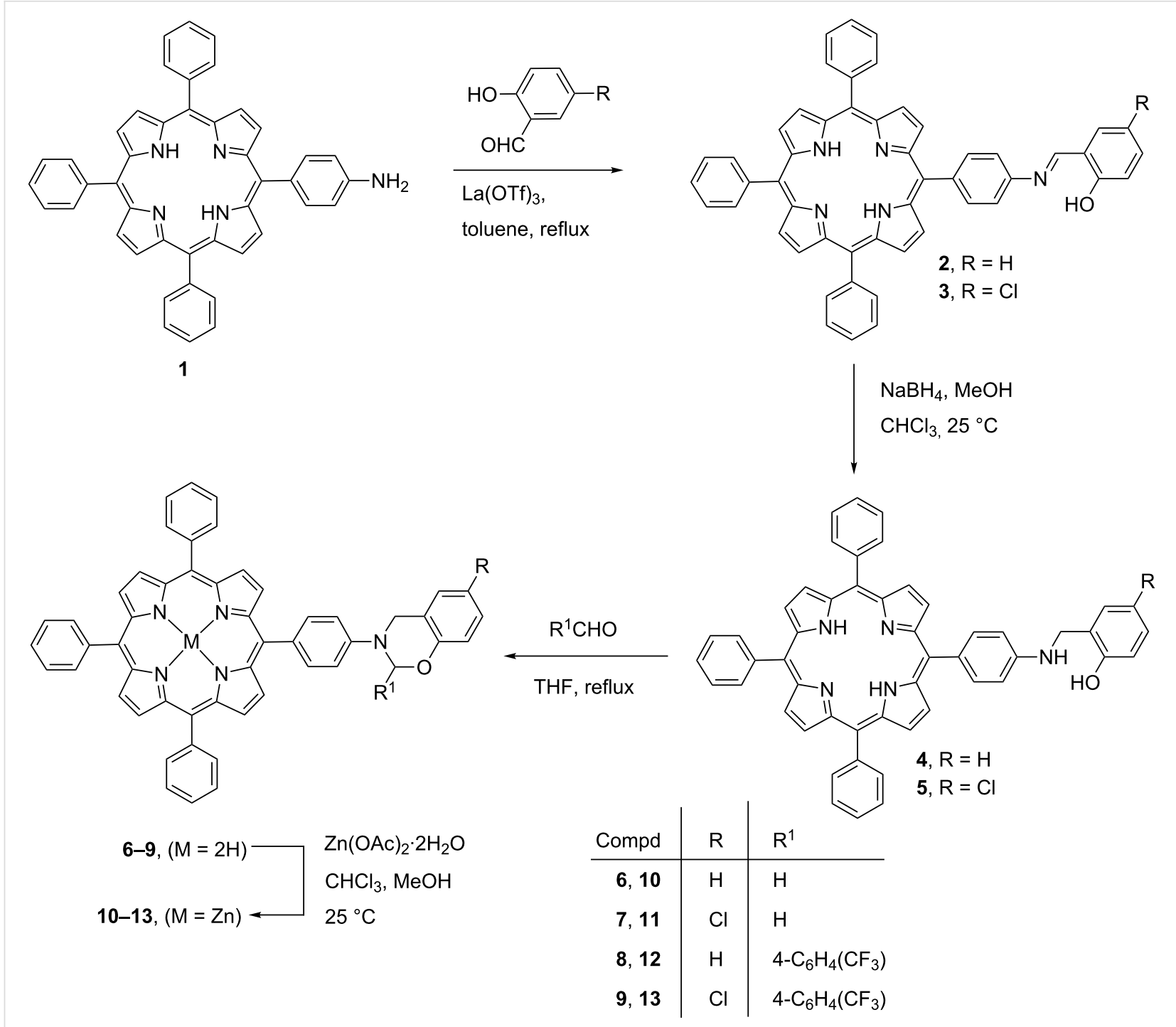


with $\alpha$ - or $\beta$-naphthol and formaldehyde in THF under reflux. After reaction with $\mathrm{Zn}(\mathrm{OAc})_{2} \cdot 2 \mathrm{H}_{2} \mathrm{O}$ in $\mathrm{CHCl}_{3} / \mathrm{MeOH}$ mixture, the free-base naphthoxazinoporphyrins 14 and $\mathbf{1 6}$ underwent zinc insertion to afford zinc (II) dihydro-1,3-naphthoxazinoporphyrins $\mathbf{1 5}$ and $\mathbf{1 7}$ in 90-92\% yields as depicted in Scheme 2.

In addition, the dimeric naphthoxazinoporphyrins 18-20 were also prepared in moderate yields through one-pot Mannich-type condensation-cyclization reaction of 5-(4-aminophenyl)$10,15,20$-triphenylporphyrin (1) with $\alpha, \alpha$ - or $\beta, \beta$ - or $\alpha, \beta$-dihydroxynaphthalenes and formaldehyde in THF under reflux (Scheme 3). Attempts have also been made to prepare the corresponding zinc naphthoxazinoporphyrin dyads, but always impure products were obtained even after repeated column chromatography.

The newly synthesized porphyrins were characterized on the basis of ${ }^{1} \mathrm{H}$ NMR, IR, mass and UV-vis data. The ${ }^{1} \mathrm{H}$ NMR spectra of all the free-base porphyrins showed a singlet around $\delta-2.7 \mathrm{ppm}$ corresponding to the internal NH protons. Iminoporphyrins 2 and $\mathbf{3}$ showed the $\mathrm{OH}$ and $\mathrm{N}=\mathrm{CH}$ protons as singlets around 13.4 and $8.9 \mathrm{ppm}$, respectively. For the aminoporphyrins 4 and 5, the hydroxy group and $\mathrm{NH}$ protons appeared as broad singlets at $8.4 \mathrm{ppm}$ and $4.3 \mathrm{ppm}$, respective- ly. The protons of the $\mathrm{CH}_{2}$ group appeared as a singlet at $4.6 \mathrm{ppm}$. The two characteristic peaks for the dihydro-1,3oxazinoporphyrins 6, 7, 10, 11 and 14-20 corresponding to $\mathrm{N}-\mathrm{CH}_{2}-\mathrm{Ar}$ and $\mathrm{N}-\mathrm{CH}_{2}-\mathrm{O}$ groups appeared as two singlets between 4 and $6 \mathrm{ppm}$. In contrast, the proton NMR spectra of dihydro-1,3-oxazinoporphyrins 8, 9, 12 and 13 showed two doublets between 4 and $5 \mathrm{ppm}$ corresponding to one proton each with a coupling constant of $16.5 \mathrm{~Hz}$ due to the coupling between two geminal protons of the $\mathrm{N}-\mathrm{CH}_{2}-\mathrm{Ar}$ group, and a characteristic singlet around 6-7 ppm for the $\mathrm{N}-\mathrm{CH}-\mathrm{O}$ proton of the oxazine ring. The IR spectra of the porphyrins 2-5 showed a peak around $3400 \mathrm{~cm}^{-1}$ corresponding to the hydroxy group. Further, the disappearance of the hydroxy peak in the IR spectra of porphyrins 6-13 confirmed the formation of the oxazine ring. Further, the electronic absorption and emission data of all the synthesized porphyrins are presented in Table 1.

The electronic absorption spectra of all the free-base dihydro1,3-oxazinoporphyrins exhibited a typical Soret band at $421 \mathrm{~nm}$ and four weaker Q bands at 518, 553, 592 and $648 \mathrm{~nm}$. In contrast, the zinc(II) dihydro-1,3-oxazinoporphyrins showed the Soret band at $426 \mathrm{~nm}$ and two Q bands at 2555 and $597 \mathrm{~nm}$. In addition, the newly prepared free-base porphyrins displayed

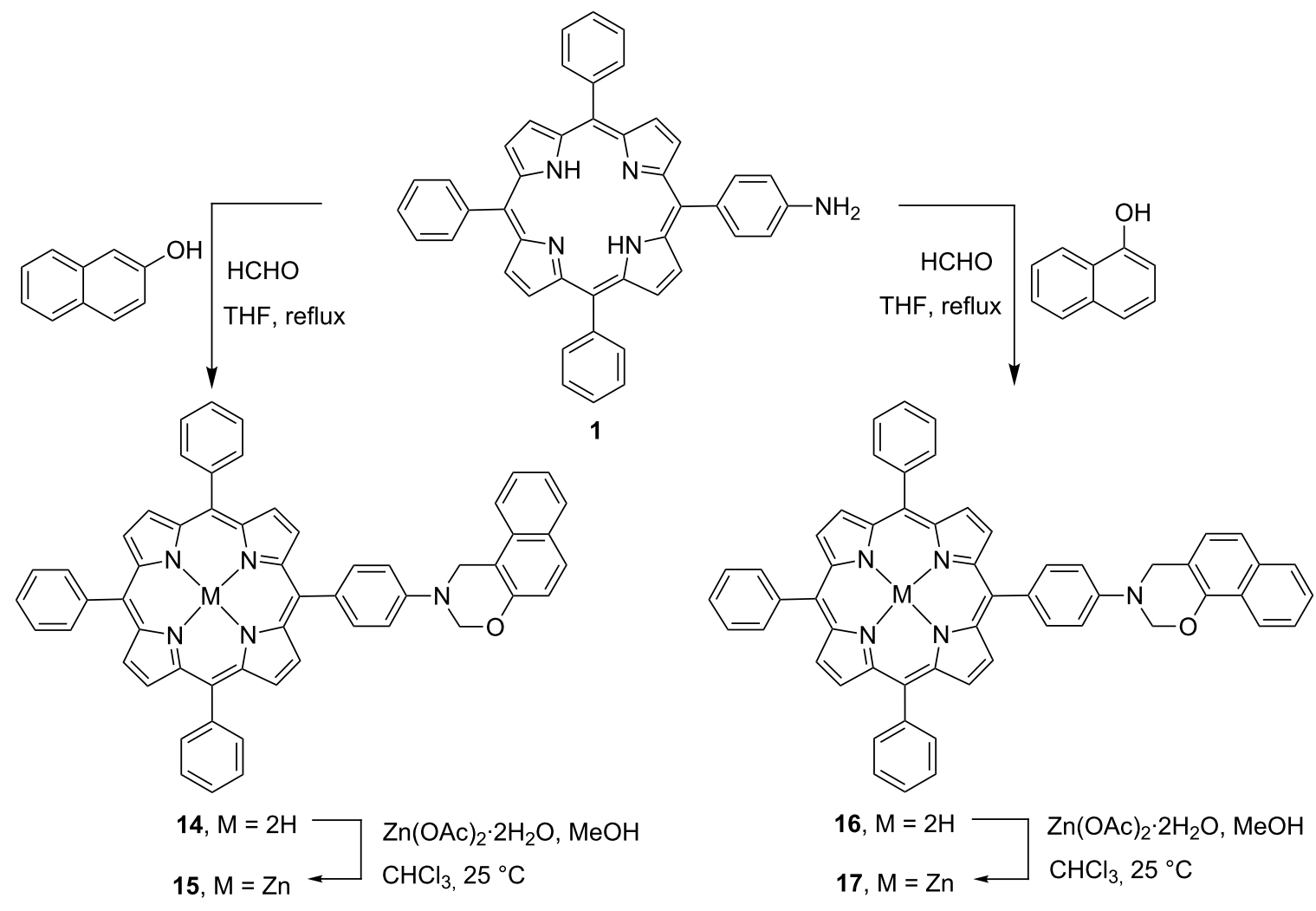

Scheme 2: Synthesis of dihydro-1,3-naphthoxazinoporphyrins. 


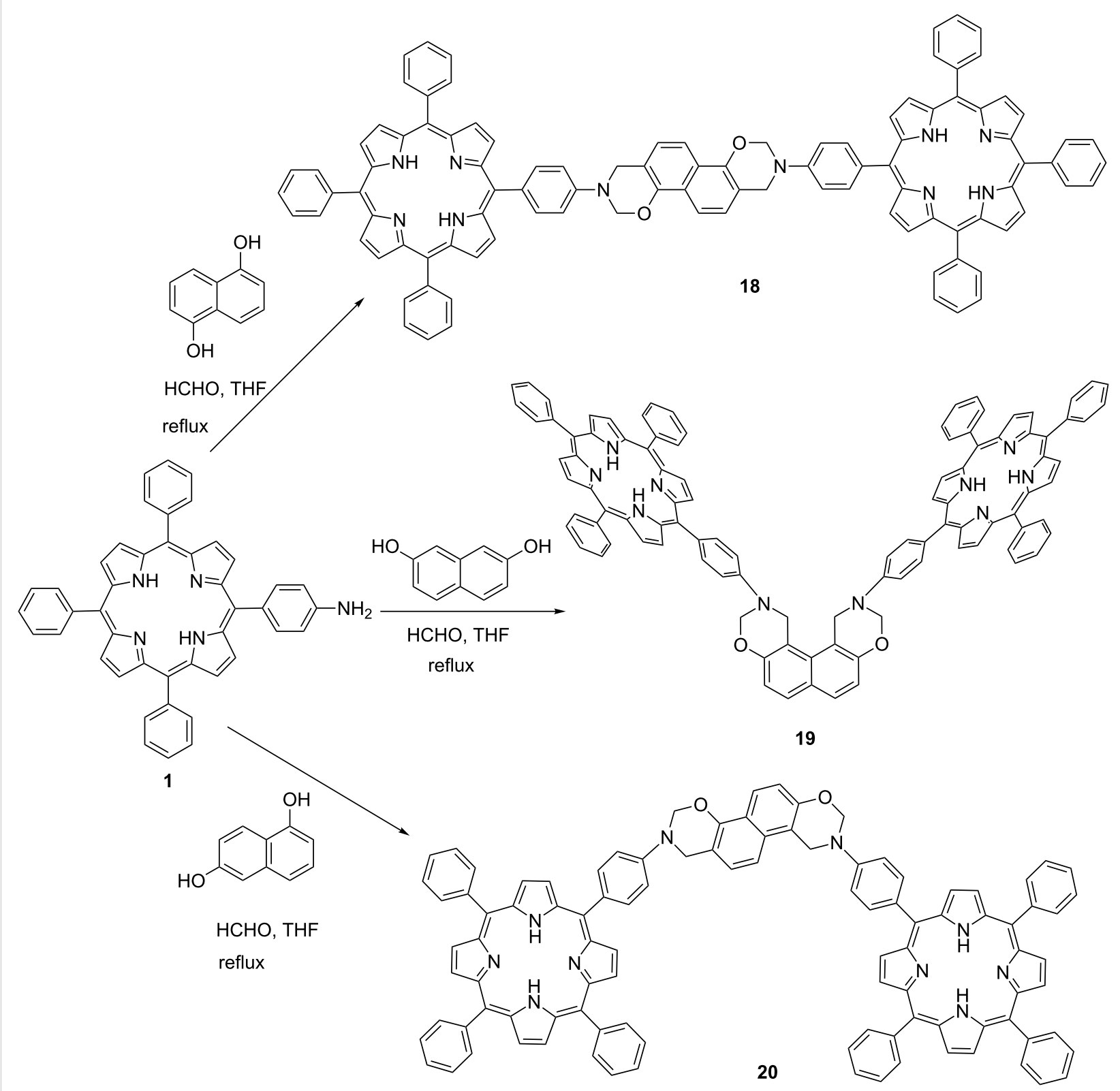

Scheme 3: Synthesis of naphtho[e]bis(dihydro-1,3-oxazinoporphyrin) derivatives.

Table 1: Electronic absorption and emission data of porphyrins (2-20).

$\begin{array}{cccc}\text { Compound } & \text { Absorption }{ }^{\mathrm{a}} \lambda_{\max }, \mathrm{nm}\left(\varepsilon \times 10^{-4}, \mathrm{M}^{-1} \mathrm{~cm}^{-1}\right) & \text { Fluorescence }\left(\lambda_{\mathrm{em}} / \mathrm{nm}\right) \\ \mathbf{2} & 421(34.68), 518(1.19), 554(1.03), 593(0.60), 648(0.51) & 652,717 \\ \mathbf{3} & 421(36.60), 517(1.91), 553(1.15), 592(0.82), 647(0.68) & 652,718 \\ \mathbf{4} & 421(46.32), 518(2.20), 553(1.25), 592(0.82), 648(0.68) & 652,718 \\ \mathbf{5} & 421(44.42), 518(1.92), 555(1.02), 592(0.59), 648(0.48) & 652,717 \\ \mathbf{6} & 421(46.82), 518(2.12), 554(1.21), 592(0.78), 649(0.66) & 652,717 \\ \mathbf{7} & 421(36.84), 518(1.90), 554(1.12), 592(0.78), 648(0.66) & 652,718 \\ \mathbf{8} & 421(52.42), 518(2.11), 553(1.36), 592(0.85), 648(0.72) & 653,718\end{array}$


Table 1: Electronic absorption and emission data of porphyrins (2-20). (continued)

$\begin{array}{lll}10 & 426(42.69), 556(1.81), 597(0.77) & 603,652 \\ 11 & 426(54.53), 555(2.26), 597(0.94) & 604,654 \\ 12 & 426(44.70), 556(1.97), 597(0.88) & 603,654 \\ 13 & 426(52.75), 555(2.35), 597(1.01) & 603,652 \\ 14 & 421(44.63), 518(1.90), 554(1.03), 593(0.60), 648(0.51) & 654,717 \\ 15 & 426(41.44), 556(1.93), 597(0.90) & 605,655 \\ 16 & 421(44.57), 518(2.11), 555(1.22), 592(0.79), 648(0.69) & 652,718 \\ 17 & 426(47.83), 556(2.27), 597(1.02) & 603,652 \\ 18 & 421(49.94), 518(2.43), 554(1.39), 593(0.79), 649(0.59) & 654,719 \\ 19 & 421(53.58), 518(2.59), 555(1.47), 592(0.89), 648(0.74) & 654,718 \\ 20 & 421(46.01), 518(2.79), 554(1.68), 592(1.17), 650(1.09) & 654,720\end{array}$

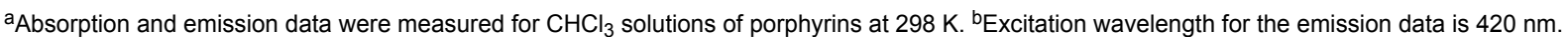

typical emission bands at $\sim 652$ and $717 \mathrm{~nm}$, whereas their zinc(II) analogues showed fluorescence bands near 603 and $652 \mathrm{~nm}$. The UV-vis and fluorescence spectra of selected free- base dihydro-1,3-oxazinoporphyrins 6, 8, 14, 16 and 18 and zinc(II) dihydro-1,3-oxazinoporphyrins 10, 12, 15 and 17 are shown in Figure 1.
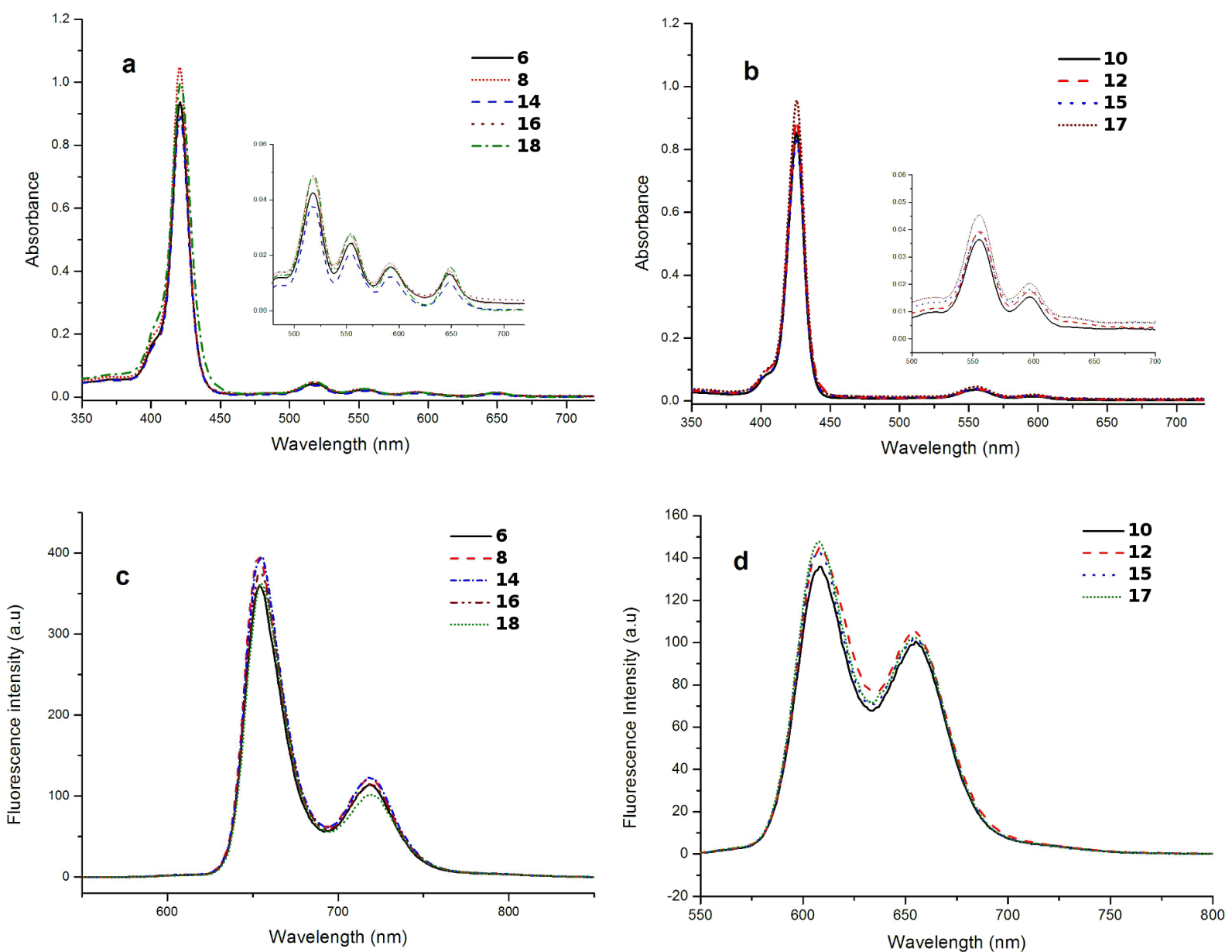

Figure 1: (a) Electronic absorption spectra of free-base porphyrins 6, 8, 14, 16 and 18 in $\mathrm{CHCl}_{3}$ at $298 \mathrm{~K}$. (b) Electronic absorption spectra of zinc porphyrins 10, 12, 15 and 17 in $\mathrm{CHCl}_{3}$ at $298 \mathrm{~K}$. Inset in both (a) and (b) shows the $\mathrm{Q}$ bands. (c) Fluorescence spectra of free-base porphyrins 6, 8, 14, 16 and 18 in $\mathrm{CHCl}_{3}\left(2 \times 10^{-6} \mathrm{~mol} \mathrm{~L}^{-1}\right)$ at $298 \mathrm{~K}, \lambda_{\mathrm{ex}}=420 \mathrm{~nm}$. (d) Fluorescence spectra of zinc porphyrins $10,12,15$ and $17 \mathrm{in} \mathrm{CHCl}_{3}$ $\left(2 \times 10^{-6} \mathrm{~mol} \mathrm{~L}^{-1}\right)$ at $298 \mathrm{~K}, \lambda_{\mathrm{ex}}=420 \mathrm{~nm}$. 


\section{Conclusion}

In summary, we have developed a convenient synthetic protocol for the construction of a new series of dihydro-1,3-oxazinoporphyrins in moderate to good yields. These novel porphyrindihydro-1,3-oxazine hybrids may be considered as potential candidates not only for biological evaluations but also for the development of newer $\pi$-conjugated molecules for various material applications.

\section{Supporting Information}

\section{Supporting Information File 1}

Experimental details and characterization data [http://www.beilstein-journals.org/bjoc/content/ supplementary/1860-5397-9-53-S1.pdf]

\section{Acknowledgements}

We thank the University of Delhi, India for providing financial support. Satyasheel is grateful to the Council of Scientific and Industrial Research, New Delhi, India for a Senior Research Fellowship.

\section{References}

1. Aratani, N.; Kim, D.; Osuka, A. Acc. Chem. Res. 2009, 42, 1922-1934. doi:10.1021/ar9001697

2. Balaban, T. S. Acc. Chem. Res. 2005, 38, 612-623. doi:10.1021/ar040211z

3. Drain, C. M.; Varotto, A.; Radivojevic, I. Chem. Rev. 2009, 109, 1630-1658. doi:10.1021/cr8002483

4. Liu, W.; Groves, J. T. J. Am. Chem. Soc. 2010, 132, 12847-12849. doi:10.1021/ja105548x

5. Hiramatsu, R.; Kawabata, S.; Miyatake, S.-I.; Kuroiwa, T.; Easson, M. W.; Vicente, M. G. H. Lasers Surg. Med. 2011, 43, 52-58. doi:10.1002/lsm.21026

6. Gianferrara, T.; Bergamo, A.; Bratos, I.; Milani, B.; Spagnul, C.; Sava, G.; Alessio, E. J. Med. Chem. 2010, 53, 4678-4690. doi:10.1021/jm1002588

7. Winkelman, J.; Slater, G.; Grossman, J. Cancer Res. 1967, 27, 2060-2064.

8. Zhang, J.-X.; Zhou, J.-W.; Chan, C.-F.; Lau, T. C.-K.; Kwong, D. W. J.; Tam, H.-L.; Mak, N.-K.; Wong, K.-L.; Wong, W.-K. Bioconjugate Chem. 2012, 23, 1623-1638. doi:10.1021/bc300201h

9. Wild, P. J.; Krieg, R. C.; Seidl, J.; Stoehr, R.; Reher, K.; Hofmann, C.; Louhelainen, J.; Rosenthal, A.; Hartmann, A.; Pilarsky, C.; Bosserhoff, A. K.; Knuechel, R. Mol. Cancer Ther. 2005, 4, 516-528. doi:10.1158/1535-7163.MCT-04-0141

10. Robinson, G. D., Jr.; Alavi, A.; Vaum, R.; Staum, M. J. Nucl. Med. 1986, 27, 239-242.

11. Ethirajan, M.; Chen, Y.; Joshi, P.; Pandey, R. K. Chem. Soc. Rev. 2011, 40, 340-362. doi:10.1039/b915149b

12. Celli, J. P.; Spring, B. Q.; Rizvi, I.; Evans, C. L.; Samkoe, K. S.; Verma, S.; Pogue, B. W.; Hasan, T. Chem. Rev. 2010, 110, 2795-2838. doi:10.1021/cr900300p
13. Hombrecher, H. K.; Ohm, S.; Koll, D. Tetrahedron 1996, 52, 5441-5448. doi:10.1016/0040-4020(96)00174-3

14. Mikata, Y.; Onchi, Y.; Tabata, K.; Ogura, S.-i.; Okura, I.; Ono, H.; Yano, S. Tetrahedron Lett. 1998, 39, 4505-4508. doi:10.1016/S0040-4039(98)00801-6

15. Sol, V.; Blais, J. C.; Carré, V.; Granet, R.; Guilloton, M.; Spiro, M.; Krausz, P. J. Org. Chem. 1999, 64, 4431-4444. doi:10.1021/jo982499+

16. Wang, H. M.; Jiang, J. Q.; Xiao, J. H.; Gao, R. L.; Lin, F. Y.; Liu, X. Y. Chem.-Biol. Interact. 2008, 172, 154-158. doi:10.1016/j.cbi.2007.11.016

17. Weimin, S.; Gen, Z.; Guifu, D.; Yunxiao, Z.; Jin, Z.; Jingchao, T. Bioorg. Med. Chem. 2008, 16, 5665-5671. doi:10.1016/j.bmc.2008.03.063

18. Shi, W. M.; Wu, J.; Wu, Y. F.; Qian, K. X. Chin. Chem. Lett. 2004, 15, 1427-1429.

19. Hamblin, M. R.; Newman, E. L. J. Photochem. Photobiol., B 1994, 26, 45-56. doi:10.1016/1011-1344(94)85035-6

20. Viola, A.; Mannoni, P.; Chanon, M.; Julliard, M.; Mehta, G.; Maiya, B. G.; Muthusamy, S.; Sambaiah, T. J. Photochem. Photobiol., B 1997, 40, 263-273. doi:10.1016/S1011-1344(97)00067-5

21. Hombrecher, H. K.; Schell, C. Bioorg. Med. Chem. Lett. 1996, 6, 1199-1202. doi:10.1016/0960-894X(96)00201-6

22. Ibrahim, H.; Kasselouri, A.; You, C.; Maillard, P.; Rosilio, V.; Pansu, R.; Prognon, P. J. Photochem. Photobiol., A 2011, 217, 10-21. doi:10.1016/j.jphotochem.2010.09.008

23. Sol, V.; Chaleix, V.; Champavier, Y.; Granet, R.; Huang, Y.-M.; Krausz, P. Bioorg. Med. Chem. 2006, 14, 7745-7760. doi:10.1016/j.bmc.2006.08.004

24. Liang, G.; Wang, L.; Yang, Z.; Koon, H.; Mak, N.; Chang, C. K.; Xu, B. Chem. Commun. 2006, 5021-5023. doi:10.1039/b611557h

25. Koo, M.-S.; Ozawa, T.; Santos, R. A.; Lamborn, K. R.; Bollen, A. W.; Deen, D. F.; Kahl, S. B. J. Med. Chem. 2007, 50, 820-827. doi:10.1021/jm060895b

26. Cheng, H.; Ma, J. S.; Zhang, D. H.; Chen, Q. Q. Synth. Commun. 2001, 31, 1941-1945. doi:10.1081/SCC-100104409

27. Silva, A. M. G.; Lacerda, P. S. S.; Tomé, A. C.; Neves, M. G. P. M. S.; Silva, A. M. S.; Cavaleiro, J. A. S.; Makarova, E. A.; Lukyanets, E. A. J. Org. Chem. 2006, 71, 8352-8356. doi:10.1021/jo0611770

28. Guo, C.-C.; Li, H.-P.; Zhang, X.-B. Bioorg. Med. Chem. 2003, 11, 1745-1751. doi:10.1016/S0968-0896(03)00027-0

29. Cavaleiro, J. A. S.; Neves, M. G. P. M.; Tomé, A. C.; Silva, A. M. S.; Faustino, M. A. F.; Lacerda, P. S.; Silva, A. M. G. J. Heterocycl. Chem. 2000, 37, 527-534. doi:10.1002/jhet.5570370310

30. Pandey, R. K.; Shiau, F.-Y.; Medforth, C. J.; Dougherty, T. J.; Smith, K. M. Tetrahedron Lett. 1990, 31, 7399-7402. doi:10.1016/S0040-4039(00)88499-3

31. Mathew, B. P.; Kumar, A.; Sharma, S.; Shukla, P. K.; Nath, M. Eur. J. Med. Chem. 2010, 45, 1502-1507. doi:10.1016/j.ejmech.2009.12.058

32. Chylińska, J. B.; Janowiec, M.; Urbański, T. Br. J. Pharmacol. 1971, 43, 649-657. doi:10.1111/j.1476-5381.1971.tb07194.x

33. Latif, N.; Mishriky, N.; Assad, F. M. Aust. J. Chem. 1982, 35, 1037-1043. doi:10.1071/CH9821037

34. Cocuzza, A. J.; Chidester, D. R.; Cordova, B. C.; Jeffrey, S.; Parsons, R. L.; Bacheler, L. T.; Erickson-Viitanen, S.; Trainor, G. L.; Ko, S. S. Bioorg. Med. Chem. Lett. 2001, 11, 1177-1179. doi:10.1016/S0960-894X(01)00192-5

35. Duffin, W. M.; Rollo, I. M. Br. J. Pharmacol. Chemother. 1957, 12, 171-175. doi:10.1111/j.1476-5381.1957.tb00116.x 
36. Kuehne, M. E.; Konopka, E. A. J. Med. Chem. 1962, 5, 257-280. doi:10.1021/jm01237a005

37. Chylińska, J. B.; Urbański, T.; Mordarski, M. J. Med. Chem. 1963, 6, 484-487. doi:10.1021/jm00341a004

38. Sharma, S.; Nath, M. New J. Chem. 2011, 35, 1630-1639. doi:10.1039/c1nj20248k

39. Sharma, S.; Nath, M. J. Heterocycl. Chem. 2012, 49, 88-92. doi:10.1002/jhet.664

40. Sharma, S.; Nath, M. Dyes Pigm. 2012, 92, 1241-1249. doi:10.1016/j.dyepig.2011.07.022

41. Bhatt, R. K.; Sharma, S.; Nath, M. Monatsh. Chem. 2012, 143, 309-316. doi:10.1007/s00706-011-0625-0

42. Kruper, W. J., Jr.; Chamberlin, A. T.; Kochanny, M. J. Org. Chem. 1989, 54, 2753-2756. doi:10.1021/jo00272a057

\section{License and Terms}

This is an Open Access article under the terms of the Creative Commons Attribution License

(http://creativecommons.org/licenses/by/2.0), which permits unrestricted use, distribution, and reproduction in any medium, provided the original work is properly cited.

The license is subject to the Beilstein Journal of Organic Chemistry terms and conditions:

(http://www.beilstein-journals.org/bjoc)

The definitive version of this article is the electronic one which can be found at: doi:10.3762/bjoc. 9.53 